DOI: https://doi.org/10.47405/mjssh.v6i4.752

\begin{tabular}{|c|c|}
\hline 4.581 & Malaysian Journal of Social Sciences and Humanities (MJSSH) \\
\hline $\begin{array}{l}\text { Malaysian Journal of } \\
\text { Social cciences and }\end{array}$ & Volume 6, Issue 4, April 2021 \\
\hline (MJ-SSH) & e-ISSN : 2504-8562 \\
\hline & $\begin{array}{l}\text { Journal home page: } \\
\text { www.msocialsciences.com }\end{array}$ \\
\hline
\end{tabular}

\title{
Tahap Kepuasan Pembelajaran Matematik Atas Talian Semasa Pandemik COVID-19
}

\author{
Juwairiah Mustapah' ${ }^{1}$, Roslinda Rosli ${ }^{1}$ \\ ${ }^{1}$ Fakulti Pendidikan, Universiti Kebangsaan Malaysia (UKM)
}

Correspondence: Juwairiah Mustapah (juwairiah.mustapah@yahoo.com)

\begin{abstract}
Abstrak
Perintah Kawalan Pergerakan (PKP) telah dilaksanakan secara berperingkat iaitu bermula 18 Mac 2020 di bawah Akta Pencegahan dan Pengawasan Penyakit Berjangkit 1988 dan Akta Polis 1967 (Ashley Tang 2020) dan tindakan undang-undang akan dikenakan kepada mereka yang gagal mematuhi arahan PKP (Kementerian Kesihatan Malaysia 2020). Salah satu kandungan PKP adalah penutupan semua institusi pendidikan selaras dengan saranan daripada UNESCO (Kementerian Kesihatan Malaysia 2020). Oleh itu, Kementerian Pelajaran Malaysia (KPM) telah mengambil inisiatif untuk menggantikan pembelajaran bersemuka kepada pembelajaran atas talian. Inisiatif ini dititikberatkan kepada calon Sijil Pelajaran Malaysia (SPM) kerana mereka sangat terkesan dengan perubahan kaedah pembelajaran secara mengejut. Kajian ini di laksanakan untuk mengenal pasti tahap kepuasan calon SPM 2020 terhadap pembelajaran matematik atas talian secara sycncronus yang dijalankan sepanjang tempoh pelaksanaan Perintah Kawalan Pergerakan (PKP). Bagi mencapai objektif kajian, dua soal selidik sedia ada digunakan iaitu Student Satisfaction Scale (SSS) dan Community of inquiry (CoI). Hasil daripada kajian tinjauan, calon SPM 2020 di pusat peperiksaan SMK Seri Kundang mempunyai tahap kepuasan yang tinggi $(\min =191.90, \mathrm{sp}=20.49)$ terhadap pembelajaran matematik secara atas talian. Di samping itu, ujian-t sampel bebas digunakan untuk membandingkan min skor kepuasan calon SPM 2020 di mana tiada perbezaan yang besar antara min tahap kepuasan pembelajaran matematik secara atas talian bagi calon kerajaan dengan calon persendirian. Manakala, ujian korelasi Pearson dilaksanakan dan mendapati bahawa terdapat hubungan yang positif antara tahap pengalaman pembelajaran matematik dalam talian $(M=67.03, S D=7.57)$ dengan persekitaran pembelajaran matematik atas talian $(M=$ $123.86, S D=14.20)$.
\end{abstract}

Kata kunci: kepuasan pembelajaran, persekitaran pembelajaran, pembelajaran matematik atas talian, pandemik COVID-19, calon SPM

\section{Satisfaction of Mathematics Online Learning during the COVID-19 Pendemic}

\begin{abstract}
The Movement Control Order (MCO) has been implemented in stages beginning March 18, 2020 under the Prevention and Control of Infectious Disease Act 1988 and the Police Act 1967 (Ashley Tang 2020) and legal action will be taken against those who fail to comply with the MCO (Ministry of Health Malaysia 2020). One of the contents of the MCO is the closure of all educational institutions in accordance with the recommendations of UNESCO (Ministry of Health Malaysia 2020). Therefore, the Ministry of Education of Malaysia $(\mathrm{MoE})$ has taken the initiative to replace face-to-face learning in online learning. This initiative is focused on "Sijil Pelajaran Malaysia" (SPM) candidates as they are
\end{abstract}


DOI: https://doi.org/10.47405/mjssh.v6i4.752

very impressed with the sudden change in learning methods. This study was conducted to identify the level of satisfaction of SPM 2020 candidates for math online learning (sycncronus) which is carried out during the execution period of the Movement Control Order (MCO). To achieve the research objectives, two existing questionnaires were used Student Satisfaction Scale (SSS) and Community of inquiry (CoI). As a result of the survey, SPM 2020 candidates at the SMK Seri Kundang examination center had a high level of satisfaction $(\min =191.90, \mathrm{sp}=20.49)$ on online math learning. In addition, independent sample t-tests are used to compare SPM 2020 candidate satisfaction scores where none are available the big difference between the mean level of online math learning satisfaction for government and private candidates. Whereas, correlation test Pearson was implemented and found that there was a positive relationship between the levels of online math learning experience ( $M=67.03, S D=7.57$ ) with an online math learning environment ( $M=123.86, S D=14.20)$.

Keywords: learning satisfaction, Learning environment, mathematics online learning, COVID-19 pandemic, SPM candidate

\section{Pengenalan}

COVID-19 adalah penyakit berjangkit yang disebabkan oleh severe acute respiratory syndorome coronavirus 2 (SARS-CoV-2) yang menyebabkan seluruh dunia dilanda pandemik dan mengakibatkan berjuta-juta kematian. Sehubungan dengan itu, COVID-19 juga menular dengan cepat iaitu melalui sentuhan pada permukaan yang di cemari oleh virus daripada individu yang telah berjangkit kepada individu lain dan melalui titisan pernafasan seperti batuk atau bersin (Kementerian Kesihatan Malaysia 2020). Oleh yang demikian, kebanyakan pemerintah negara di seluruh dunia telah membuat keputusan untuk menutup sementara institusi pendidikan supaya dapat memutuskan rantaian COVID-19. Hal ini telah menjejaskan hampir $80 \%$ daripada populasi pelajar di dunia iaitu hampir 1.37 bilion pelajar daripada 138 negara dan 60.2 juta guru tidak dapat berada di dalam kelas oleh kerana penutupan sekolah dan universiti (UNESCO 2020).

Sehubungan dengan itu, kerajaan Malaysia telah mengisytiharkan pelaksanaan Perintah Kawalan Pergerakan (PKP) secara berperingkat iaitu bermula 18 Mac 2020 di bawah Akta Pencegahan dan Pengawasan Penyakit Berjangkit 1988 dan Akta Polis 1967 (Ashley Tang 2020) dan tindakan undangundang akan di kenakan kepada mereka yang gagal mematuhi arahan PKP (Kementerian Kesihatan Malaysia 2020). Dalam kandungan PKP, terdapat enam arahan di mana salah satunya telah mengikut saranan daripada UNESCO iaitu penutupan semua institusi pendidikan termasuk taska, sekolah kerajaan dan swasta, institusi pendidikan sekolah rendah, menengah dan pra-universiti (Kementerian Kesihatan Malaysia 2020). Oleh itu, KPM telah mengambil inisiatif untuk menggantikan kaedah pendidikan di Malaysia iaitu pembelajaran bersemuka di dalam kelas ditukarkan kepada pembelajaran atas talian. Inisiatif ini dititikberatkan kepada pelajar yang bakal menduduki peperiksaan besar iaitu Sijil Pelajaran Malaysia (SPM) kerana calon SPM merupakan pelajar yang sangat terkesan dengan perubahan kaedah pembelajaran secara mengejut.

\section{Pernyataan Masalah}

Pembelajaran atas talian merupakan salah satu pendekatan yang menggunakan teknologi digital untuk menghubungkan guru dan pelajar yang tidak dapat bersemuka di dalam kelas. Pendekatan ini boleh di aplikasikan kepada semua peringkat pendidikan dengan hanya menggunakan komputer atau peranti. Pembelajaran atas talian juga merupakan satu keperluan yang penting dalam dunia pendidikan ketika penularan wabak COVID-19 di mana pertemuan bersemuka antara pelajar dan guru di gantikan dengan pertemuan atas talian dengan menggunakan aplikasi persidangan video seperti Cisco WebEx, Zoom, Skype, MS Team dan Google Meet. Perkembangan pembelajaran dalam talian memerlukan dua jenis sumber iaitu digital dan teknologi (Zhu, 2020). Antara sumber digital adalah video pendidikan, pengajaran melalui platform, persidangan video, rangkaian media sosial dan banyak lagi sumber digital (Shakah et al., 2019). Manakala dari segi teknologi pula, sumbernya adalah komputer desktop, 
DOI: https://doi.org/10.47405/mjssh.v6i4.752

komputer riba, tablet, telefon pintar dan televisyen (Laskaris et al., 2019). Jika guru atau pelajar mempunyai kedua-dua sumber ini namun tidak mempunyai capaian akses internet yang berkualiti, akan menjadi salah satu cabaran dalam proses pengajaran dan pembelajaran.

Capaian rangkaian internet juga sering menjadi isu yang sering dibangkitkan dalam pembelajaran secara atas talian (Nor Shela \& Mohd Shafie, 2020). Namun begitu, rangkaian internet di Malaysia kini semakin diperbaharui dan mampu dimiliki dengan perkhidmatan yang disediakan oleh syarikat-syarikat telco di Malaysia (Aziz, 2015). Oleh itu, tiada lagi alasan dan panik untuk mendapatkan teknologi baru bagi mencapai objektif pembelajaran itu sendiri. Walau bagaimanapun, terdapat juga masalah yang dihadapi oleh pelajar untuk pembelajaran atas talian seperti kurang disiplin diri, kesesuaian bahan pembelajaran, kemudahan capaian internet, persekitaran pembelajaran yang baik semasa pengasingan diri di rumah (Bao, 2020). Pelajar yang mengikuti pembelajaran dalam talian untuk pertama kalinya lebih cenderung kepada perasaan keseorangan di mana mereka berasa diri mereka terasing dari sosial. Hal ini kerana persekitaran yang baru dan tidak biasa dengan komuniti pembelajaran dalam talian (Taeho \& Richardson, 2015).

Dalam konteks pendidikan matematik, pembelajaran matematik atas talian hanya disediakan kepada pendidikan di peringkat tinggi seperti di universiti, namun di sebabkan seluruh dunia menghadapi penularan COVID-19 dan keadaan yang sangat membimbangkan, semua pendidikan termasuk pendidikan matematik di peringkat rendah sehingga peringkat tinggi dilaksanakan secara atas talian (UNESCO, 2020). Kesan daripada pertukaran kaedah pendidikan secara mengejut, guru-guru sering kali mendengar rungutan pelajar yang tidak memahami sesuatu subjek terutamanya subjek matematik di sebabkan oleh proses pengajaran dan pembelajaran (PdP) tidak dapat dilaksanakan secara bersemuka. Perkara ini juga menjadi salah satu isu dalam kepuasan pembelajaran matematik dalam talian. Namun, kajian yang dijalankan berdasarkan tahap kepuasan pelajar sekolah menengah terhadap pembelajaran matematik dalam talian. Justeru itu, kajian ini diharapkan dapat memenuhi kekurangan yang sedia ada supaya dapat mencetuskan idea bagi kajian lanjutan pada peringkat yang lebih tinggi. Kajian yang berkaitan tahap kepuasan pelajar terhadap pembelajaran matematik dalam talian seperti kajian ini, dapat memberikan gambaran kepada guru matematik sekolah menengah atas dan calon SPM tentang kemahiran dan kegunaan Teknologi Maklumat dan Komunikasi (TMK) dalam pendidikan matematik.

Oleh itu, terdapat keperluan untuk menjalankan satu kajian yang menyeluruh antara persekitaran pembelajaran matematik dalam talian dengan kepuasan pembelajaran matematik atas talian. Kajian ini di laksanakan untuk mengenal pasti tahap kepuasan calon SPM terhadap pembelajaran matematik atas talian secara sycncronus yang dijalankan sepanjang tempoh pelaksanaan Perintah Kawalan Pergerakan (PKP). Kajian ini difokuskan kepada pelajar yang bakal menduduki SPM tahun 2020 kerana pelajar ini lebih terkesan dengan perubahan kaedah pembelajaran secara mengejut disebabkan oleh wabak COVID-19 yang menular dengan cepat di seluruh dunia. Bagi mencapai tujuan kajian tersebut, tiga persoalan kajian telah dibina oleh pengkaji iaitu:

i. Apakah tahap kepuasan calon SPM terhadap pembelajaran matematik dalam talian dari segi pengalaman dan persekitaran?

ii. Apakah terdapat perbezaan tahap kepuasan pembelajaran matematik secara dalam talian antara calon kerajaan dengan calon persendirian?

iii. Sejauh manakah hubungan antara pengalaman pembelajaran dan persekitaran pembelajaran matematik dalam talian bagi calon SPM 2020?

\section{Pembelajaran Matematik Atas Talian}

Menurut Smith dan Ferguson (2005), salah satu punca utama berlakunya penurunan dalam pembelajaran matematik secara dalam talian adalah kerana persekitaran ini tidak sesuai terhadap subjek matematik di mana cabaran tertentu seperti penyelesaian masalah dalam pendidikan matematik menjadi lebih sukar untuk mengajar dan belajar dalam talian. Sedangkan penyelesaian masalah adalah penting dalam pendidikan matematik. Berdasarkan pengalaman pengkaji sendiri, pembelajaran 
matematik tidak sesuai dilaksanakan dalam talian kerana pelajar tidak dapat berinteraksi dengan guru secara terus semasa proses pengajaran dan pemudahcaraan (PdPc) sedang berlangsung. Hal ini kerana kebiasaannya pelajar lebih cenderung bertanya soalan yang kurang faham melalui penulisan atau berdasarkan hasil jalan kerja mereka di mana pelajar tidak mahir bertanyakan soalan matematik dengan menggunakan ayat matematik. Selaras dengan pendapat Jaggars (2014), di mana pembelajaran matematik dalam talian menjadi lebih mencabar kepada pelajar apabila kekurangan beberapa faktor persekitaran pembelajaran seperti faktor motivasi, rasa terasing dan kekurangan sokongan sosial dalam persekitaran pembelajaran dalam talian.

Selain daripada luahan pelajar tentang persekitaran pembelajaran matematik dalam talian, pengajar juga sering mengadu bahawa sistem pengajaran matematik dalam talian sekarang mempunyai kekurangan seperti tidak menyokong tata tanda atau simbol, formula dan rajah matematik (Peidi \& Youngjin, 2019). Keseluruhannya, kepuasan pelajar terhadap pembelajaran dalam talian dapat dikenal pasti daripada beberapa faktor iaitu interaksi dan komunikasi antara pengajar dan pelajar, jumlah masa terhadap tugasan, pembelajaran aktif dan kerjasama dalam kalangan rakan sekelas. Selaras dengan pendapat Davis (2017), di mana pembelajaran matematik dalam talian yang berkesan memerlukan penggunaan bentuk pedagogi pembelajaran dalam talian yang betul dan berkesan serta guru mengekalkan komunikasi yang aktif antara pelajar dan guru atau pelajar dan pelajar lain.

Dalam bidang pendidikan matematik juga sering menjadi isu apabila ramai ibu bapa mengadu bahawa tahap pencapaian anak-anak di sekolah terjejas di sebabkan oleh matematik kerana kesukaran pelajar untuk memahami mata pelajaran itu sendiri semasa di dalam kelas. Jika kaedah bersemuka juga telah berlaku kesukaran untuk memahami konsep matematik bagaimana pula dengan pendekatan matematik secara atas talian?. Smith dan Ferguson (2005) yang menyatakan bahawa sistem e-pembelajaran kurang sesuai digunakan bagi mata pelajaran matematik dan persekitaran pembelajaran dalam talian juga memberi cabaran dalam pembelajaran matematik. Walau bagaimanapun, pemahaman Ferguson (2005) bercanggah dengan Ahn dan Edwin (2018) yang menyatakan bahawa pembelajaran matematik dalam talian merupakan satu pendekatan yang berkesan dan menjadikan mata pelajaran matematik lebih menarik serta bermakna kepada pelajar. Oleh kerana dunia sedang berhadapan dengan pandemik COVID-19, pendekatan ini sesuai di laksanakan sepanjang penutupan sekolah di sebabkan oleh Perintah Kawalan Pergerakan (PKP) dan berkemungkinan penerapan ini dapat menghasilkan kepuasan pelajar terhadap pembelajaran matematik.

Di samping itu, persekitaran pembelajaran matematik dalam talian juga memainkan peranan penting terhadap pembelajaran aktif (Chin et al., 2017). Dalam persekitaran pembelajaran matematik dalam talian, pengajar juga boleh mengumpul maklumat kehadiran pelajar berdasarkan data log masuk, tempoh masa penglibatan dalam talian dan pandangan pelajar terhadap kandungan pembelajaran (Alzahrani, 2017). Komitmen atau kerjasama daripada pelajar dan kecekapan pelajar dalam mengendalikan aplikasi atau komputer juga menjadi isu dalam pembelajaran aktif semasa proses pembelajaran matematik dalam talian (Aziz, 2015). Berdasarkan pengalaman pengkaji sendiri semasa peroses pengajaran dan pembelajaran matematik secara synchronous, kebanyakan pelajar yang menghadiri kelas secara talian tidak membuka video dan mematikan suara (mute) semasa proses PdP sedang berlangsung. Pembelajaran secara synchronous juga menjadi salah satu punca pelajar letih kerana terlalu lama menumpukan perhatian terhadap peranti elektronik di mana tempoh masa pembelajaran telah ditetapkan oleh guru (Wasdahl, 2020). Hal ini menyebabkan suasana pembelajaran dalam matematik dalam talian tidak sama seperti suasana di dalam kelas matematik kerana guru tidak mendapat respons daripada pelajar apabila soalan dikemukakan. Perkara ini menjadi salah satu punca suasana pengajaran seringkali berpusatkan kepada guru kerana kebiasaannya pelajar tidak dapat bertanya semasa latihan diberikan (Didin, Mardiono \& Yanuarso, 2020).

\section{Kepuasan Pembelajaran Atas Talian}

Kepuasan merupakan suatu pertimbangan atau keputusan yang menyediakan tahap penggunaan terhadap sesuatu ciri produk dan perkhidmatan, atau produk dan perkhidmatan itu sendiri (Parahoo et al., 2016). Manakala, kepuasan pembelajaran pula mewakili konstruk sikap pelajar dan mengukur 
aspek dengan afektif di mana pelajar yang berpuas hati kebiasaannya mempunyai pengalaman pembelajaran yang positif dalam pembelajaran atas talian (Chin et a., 12017).

Kunci utama bagi keberhasilan pembelajaran atas talian adalah kepuasan pelajar terhadap kaedah pembelajaran itu sendiri (Dziuban et al., 2015; Rios, Elliot \& Mandernach, 2018). Kepuasan merupakan salah satu langkah penting untuk menentukan kualiti sesuatu pendidikan dalam talian. Manakala, kepuasan pelajar adalah persepsi pelajar terhadap pengalaman pembelajaran iaitu sejauh mana persekitaran pembelajaran yang menyokong pencapaian akademik di mana pelajar yang mempunyai kepuasan yang tinggi dapat mencetuskan pemikiran dan pembelajaran terhadap kaedah pengajaran (Harsasi \& Sutawijaya, 2018; Alqurasi, 2019). Terdapat empat faktor yang mempengaruhi kepuasan pelajar terhadap pembelajaran dalam talian iaitu i) komunikasi dan interaksi antara pengajar dan pelajar; ii) jumlah masa terhadap tugasan; iii) penglibatan dan pembelajaran aktif dan iv) kerjasama di antara rakan sekelas. (Gary \& Diloreto, 2016). Kepuasan pelajar dalam pembelajaran secara atas talian akan meningkat apabila pembelajaran dirancang supaya dapat membuat refleksi pembelajaran dan penyediaan platform yang sesuai untuk berinteraksi dan bekerjasama antara guru bersama pelajar atau pelajar bersama pelajar (Rios, Elliott, \& Mandernach, 2018).

Beberapa kajian lepas telah dilaksanakan untuk mengukur tahap kepuasan pelajar terhadap pembelajaran dalam talian (Gary \& Diloreto, 2016; Majed, 2017; Harsasi \& Sutawijaya, 2018; Nortvig et al., 2018). Manakala dari segi pendidikan matematik pula, kajian lepas agak terhad dimana di peringkat pengajian tinggi terhadap pembelajaran matematik dalam talian (Boz \& Adnan, 2017; Mayer et al., 2017; Reju \& Jita, 2018). Namun begitu, pelajar tidak berpuas hati terhadap pembelajaran matematik dalam talian namun tidak dinyatakan sebab-sebab yang mendorong ketidakpuasan pelajar (Davis, 2016). Di samping itu, Jaggars (2014) mendapati bahawa 40 peratus respondennya tidak suka mengikuti pembelajaran matematik secara dalam talian kerana matematik merupakan subjek yang sukar. Akan tetapi, masih tidak banyak kajian mengenai kepuasan pelajar sekolah menengah terhadap pembelajaran matematik dalam talian. Walau bagaimanapun, dari segi usia, pelajar muda lebih berpuas hati terhadap pembelajaran matematik dalam talian dibandingkan pelajar yang berusia (Davis, 2014). Namun begitu, tidak terdapat kajian yang dilaksanakan terhadap pelajar sekolah menengah. Hal yang sedemikian menjadi salah satu cabaran untuk melaksanakan pembelajaran dalam talian bagi pendidikan matematik di peringkat sekolah menengah kerana kurangnya keputusan dan perbincangan mengenai keberkesanan kaedah pembelajaran ini. Oleh itu, tujuan kajian ini dilaksanakan adalah untuk mengenal pasti kepuasan pelajar sekolah menengah terhadap pembelajaran matematik dalam talian.

\section{Model Pembelajaran Atas Talian}

Model Community of Inquiry (CoI) merupakan satu model yang telah dibina oleh Garrison, Anderson dan Archer (1999) sebagai model pengalaman pembelajaran dalam talian berdasarkan tiga elemen yang berbeza iaitu sosial, kognitif, dan pengajaran. Model CoI juga merupakan salah satu model yang menjadi rujukan kepada kajian tentang kepuasan pelajar terhadap pembelajaran dalam talian (Garrison \& Akyol, 2011). Oleh itu, model CoI dapat menyokong pembelajaran dalam talian di mana persekitaran pembelajarannya yang bergantung kepada perkongsian pengajar dan pelajar seperti perkongsian idea, maklumat dan pendapat. Menurut Picciano (2017), model CoI adalah salah satu model yang popular bagi pembelajaran dalam talian dan menjadi sangat interaktif dalam kalangan pengajar dan pelajar yang menggunakan persidangan video. Berdasarkan rajah 2.1, model CoI telah dibina berdasarkan tiga konsep elemen atau "kehadiran" yang berbeza iaitu sosial, kognitif, dan mengajar (Garrison et al., 2008) di mana model ini menerangkan bagaimana berlakunya pengalaman pembelajaran dalam talian kepada sekumpulan pelajar.

Pengalaman pembelajaran dalam rajah 1 merujuk kepada kepuasan pelajar terhadap pembelajaran berdasarkan tiga aspek kehadiran iaitu sosial, kognitif dan mengajar. Kehadiran sosial dalam model CoI merujuk kepada kemampuan peserta untuk berkomunikasi dalam komuniti kursus pengajian supaya dapat menonjolkan keperibadian masing-masing kepada komuniti di mana komunikasi tersebut mestilah mempunyai tujuan yang betul dalam persekitaran pembelajaran dalam talian (Garrison et al., 2008). Kehadiran sosial dalam model CoI ini mempunyai tiga komponen yang penting iaitu i) 
komunikasi terbuka; ii) perpaduan kumpulan; dan iii) kesan komunikasi (Garrison 2009). Kehadiran komponen-komponen ini di dalam pembelajaran secara atas talian dapat membantu pelajar untuk menjelaskan diri mereka sendiri dengan bebas, bekerjasama dengan pelajar lain dan menggambarkan emosi pelajar (Tolu, 2013).

\section{Rajah 1 Model Community of Inquiry (CoI)}

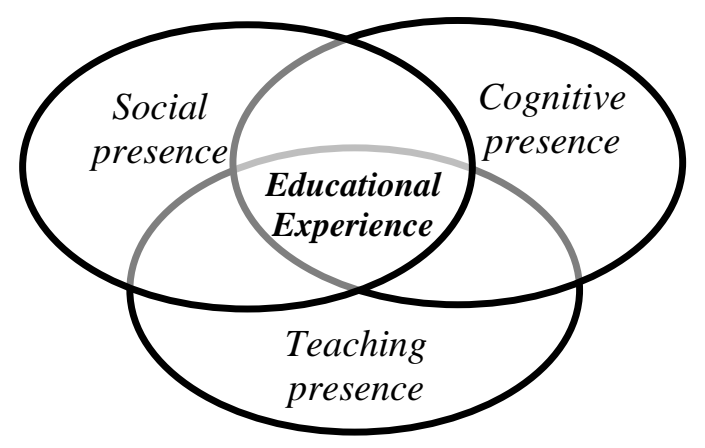

Sumber: Garrison et al. (2008)

Di samping itu, kehadiran kognitif merupakan adalah satu elemen yang terdapat dalam model CoI dan juga merupakan jantung kepada CoI (Garrison, 2009). Kehadiran kognitif menerangkan sejauh mana pelajar dapat membina dan mengesahkan makna melalui komunikasi dan refleksi yang berterusan (Garrison et al., 2008). Salah satu cara untuk meningkatkan kehadiran kognitif terhadap pembelajaran dalam talian adalah dengan merancang aktiviti yang membolehkan pelajar bekerjasama untuk menerokai, memahami, menyelesaikan dan mengaplikasikan masalah. Empat kategori kehadiran kognitif yang terdapat dalam model CoI iaitu i) pencetus kejadian; ii) penerokaan; iii) kesepaduan; dan iv) resolusi (Garrison, 2009).

Seterusnya, kehadiran mengajar adalah salah satu elemen yang terdapat dalam model CoI. Garrison et al. (2008) menyatakan bahawa kehadiran mengajar dalam CoI adalah permudahan hala tuju pedagogi kepada pelajar dalam proses sosial dan kognitif supaya dapat menghasilkan pembelajaran yang berkesan. Komunikasi dan garis panduan yang jelas bagi aktiviti pembelajaran dapat menyumbangkan impak yang positif kepada pelajar dalam keberhasilan pembelajaran atas talian (Rios, Elliott, \& Mandernach, 2018). Sebagai contoh adalah memberi maklum balas dalam tempoh 24 jam terhadap persoalan dikemukakan oleh pelajar. Terdapat tiga komponen di bawah kehadiran mengajar iaitu i) reka bentuk dan organisasi pengajaran; ii) permudahkan perbualan; dan iii) arahan secara langsung (Garrison, 2009).

\section{Metod Kajian}

\section{Reka Bentuk Kajian}

Reka bentuk kajian merupakan suatu kaedah yang tertentu untuk memperoleh data dan maklumat yang diperlukan untuk menjawab persoalan kajian dan mencapai objektif kajian (Creswell, 2012). Dalam kajian ini, reka bentuk kajian memfokuskan kepada kajian bukan eksperimental yang merupakan pendekatan kuantitatif dengan menggunakan kajian tinjauan untuk menerokai dan menghuraikan kepuasan pelajar terhadap pembelajaran matematik dalam talian. Secara tidak langsung dapat membuat ramalan berkaitan isu semasa dalam pendidikan matematik iaitu pembelajaran tidak dapat dilaksanakan secara bersemuka ketika dunia menghadapi pandemik iaitu wabak COVID-19. Menurut Chua (2014), kajian tinjauan merupakan kajian bukan eksperimen yang menggunakan borang soal selidik kepada subjek kajian. Penggunaan soal selidik juga sangat praktikal sebagai instrumen kajian kerana dapat menjimatkan masa dan kos pengkaji dalam proses pengumpulan data. Menurut Creswell (2012), 
DOI: https://doi.org/10.47405/mjssh.v6i4.752

penggunaan soal selidik banyak digunakan dalam kajian sains sosial dan pendidikan kerana data yang diperolehi daripada subjek kajian dapat menghuraikan dan menggeneralisasikan hasil kajian kepada populasi kajian.

\section{Populasi dan Sampel Kajian}

Pemilihan lokasi bagi kajian ini adalah di pusat peperiksaan Sekolah Menengah Kebangsaan Seri Kundang, Rawang Selangor dan fokus kajian adalah pelajar yang menduduki Sijil Pelajaran Malaysia (SPM) pada tahun 2020. Populasi sasaran kajian ini terdiri daripada calon SPM pada tahun 2020 iaitu calon dari sekolah kerajaan dan calon persendirian. Di pusat peperiksaan yang sama, terdapat lebih kurang 200 calon yang menduduki peperiksaan SPM pada tahun 2020. Manakala, sampel kajian pula terdiri daripada 60 orang calon SPM 2020 di pusat peperiksaan SMK Seri Kundang, Rawang Selangor yang merangkumi 30 calon SPM dari sekolah kerajaan dan selebihnya adalah calon persendirian yang di pilih daripada pusat peperiksaan yang sama.

Pemilihan sampel dibuat berdasarkan kaedah persampelan kebarangkalian melalui prosedur persampelan rawak mudah supaya setiap individu mempunyai peluang yang sama untuk dipilih sebagai sampel yang mewakili populasi kajian. Semua calon SPM tahun 2020 di pusat peperiksaan SMK Seri Kundang layak dipilih sebagai sampel dalam populasi tanpa mengira umur dan jenis calon SPM. Walau bagaimanapun, calon dari sekolah kerajaan mempunyai pengalaman belajar matematik dan persediaan menduduki peperiksaan SPM selama lima tahun iaitu semenjak tingkatan 1 hingga tingkatan 5. Manakala calon persendirian pula hanya mempunyai pengalaman belajar dan persediaan menduduki peperiksaan SPM selama setahun. Namun, aspek yang diperhatikan terhadap kedua-dua kumpulan calon ini adalah berdasarkan kepuasan pembelajaran matematik dalam talian dan persepsi pelajar terhadap persekitaran pembelajaran dalam talian sepanjang tempoh pelaksanaan Perintah Kawalan Pergerakan (PKP).

Manakala bilangan sampel bagi kajian rintis pula adalah seramai 20 calon SPM 2020 yang dipilih daripada pusat peperiksaan yang berhampiran dengan lokasi kajian iaitu SMK Bukit Rahman Putra, Sungai Buloh Selangor. Tujuan sampel dari kajian rintis ini adalah melihat kesesuaian soal selidik kajian yang di gunakan kepada responden kajian sama ada setiap item dalam soal selidik difahami dengan jelas atau tidak dan masa yang di ambil oleh responden untuk menjawab keseluruhan soalan yang terdapat dalam soal selidik yang di sediakan.

\section{Instrumen Kajian}

Instrumen yang digunakan dalam kajian ini adalah berdasarkan pada persoalan kajian yang telah di bina di mana pengkaji menggunakan soal selidik tertutup. Bagi mencapai objektif kajian, pengkaji membina 57 item instrumen dengan menggunakan dua soal selidik yang sedia ada dan soalan demografi. Instrumen kajian di bina berdasarkan soal selidik yang telah diadaptasikan iaitu gabungan dua soal selidik Bahasa Inggeris Student satisfaction scale (Bolliger \& Wasilik, 2012) dan Community of inquiry (Arbaugh, 2008).

Soal selidik Student Satisfaction Scale (SSS) digunakan untuk mengukur tahap kepuasan pelajar terhadap pembelajaran matematik dalam talian di mana aspek-aspek kepuasan pelajar dilihat berdasarkan kualiti tenaga pengajar, ciri-ciri pelajar, reka bentuk pengajaran dan hasil pembelajaran pelajar. Manakala soal selidik Community of Inquiry (CoI) digunakan untuk menilai persepsi pelajar terhadap persekitaran pembelajaran dalam konteks pembelajaran dalam talian. Tujuan utama pengkaji menggunakan soal selidik yang telah disahkan dan terbitkan adalah untuk menjimatkan masa. Soal selidik yang di gunakan dalam kajian ini mengandungi tiga bahagian iaitu;

i. Bahagian A: Demografi responden;

ii. Bahagian B: Tahap kepuasan pembelajaran matematik atas talian; dan

iii. Bahagian C: Persekitaran pembelajaran matematik atas talian. 
DOI: https://doi.org/10.47405/mjssh.v6i4.752

Bahagian A dalam soal selidik ini merupakan latar belakang responden seperti nama, umur, jantina dan jenis calon SPM. Manakala, pada Bahagian B soal selidik ini mengandungi 20 item dan pada Bahagian $\mathrm{C}$ pula mengandungi 34 item. Skala pengukuran yang terlibat dalam soal selidik ini adalah skala Likert di mana setiap item diukur menggunakan lima skala iaitu (1) sangat tidak berpuas hati; (2) tidak berpuas hati; (3) tidak pasti; (4) berpuas hati dan (5) sangat berpuas hati.

\section{Kesahan dan Kebolehpercayaan}

Kesahan dan kebolehpercayaan kajian merupakan perkara yang penting dalam sesuatu kajian supaya memperoleh dapatan kajian yang sah dan dipercayai. Kesahan kajian adalah merujuk kepada konsep mengukur apa yang sepatutnya diukur dan dianggap sah jika diukur dengan alat yang sepatutnya manakala kebolehpercayaan merujuk kepada ketetapan dan konsisten alat pengukuran mengukur sesuatu perkara atau pemboleh ubah (Fuad, 2017). Bagi mencapai objektif kajian, dua soal selidik Bahasa Inggeris yang sedia ada iaitu Student Satisfaction Scale (SSS) dan Community of inquiry (CoI) digunakan.

\section{Kesahan Soal Selidik}

Dalam proses kesahan instrumen, pengkaji menterjemahkan kedua-dua soal selidik daripada bahasa asal soal selidik ke bahasa sasaran iaitu dari Bahasa Inggeris kepada Bahasa Malaysia. Proses penterjemahan ini merujuk seorang pakar dalam bidang matematik iaitu guru matematik sekolah menengah atas yang mempunyai pengalaman mengajar lebih daripada 10 tahun. Hal ini demikian kerana pengetahuan dalam bidang merupakan satu kriteria yang diperlukan bagi seorang penterjemah untuk mengadaptasi dan menterjemahkan sesuatu instrumen kajian (Mohammad Rahim \& Wan Shahrazad, 2019). Namun begitu, proses penterjemahan ini hanya mengambil kira penterjemahan bahasa sahaja dan tidak mengambil kira perbezaan budaya kerana Boynton (2004) menyatakan bahawa instrumen yang dibina pada masa, budaya dan negara yang berbeza daripada populasi kajian semasa, berkemungkinan ukuran kesahan instrumen berbeza dengan kajian semasa.

\section{Kebolehpercayaan Soal Selidik}

Kajian terdahulu mendapati bahawa Student Satisfaction Scale (SSS) memperolehi nilai Cronbach's Alpha yang tinggi iaitu 0.94 dan hal yang demikian membuktikan bahawa instrumen ini mempunyai nilai kebolehpercayaan yang memuaskan kepada pelajar pra siswazah (Bolliger \& Wasilik, 2012). Manakala kebolehpercayaan bagi soal selidik telah dijalankan oleh Arbaugh (2008) di mana CoI mempunyai nilai Cronbach's Alpha yang tinggi bagi ketiga-tiga elemen yang di ukur dalam CoI iaitu 0.94 untuk kehadiran mengajar, 0.91 untuk kehadiran sosial dan 0.95 untuk kehadiran kognitif. Menurut Arbaugh (2008), soal selidik ini boleh dipercayai dan sesuai digunakan kepada pelajar pra siswazah. Oleh kerana kedua-dua soal selidik di gunakan kepada pelajar di peringkat pengajian tinggi, proses kebolehpercayaan instrumen dilaksanakan semula supaya dapat menentukan kesesuaian soal selidik SSS untuk mengukur tahap kepuasan pembelajaran dalam talian responden kajian ini iaitu calon SPM 2020.

Kebiasaannya, kebolehpercayaan bagi sesuatu soal selidik diukur dengan menggunakan pekali alpha apabila skala pengukuran bagi item soal selidik mempunyai beberapa pilihan seperti skala Likert (Bolarinwa, 2015). Kebolehpercayaan bagi sesuatu soal selidik boleh dikenal pasti dengan menggunakan kajian rintis melalui kutipan data daripada 20 hingga 30 responden yang tidak termasuk dalam sampel kajian sebenar (Bolarinwa, 2015). Oleh itu, seramai 20 orang calon SPM 2020 dari pusat peperiksaan yang berhampiran dengan lokasi kajian iaitu SMK Bukit Rahman Putra dipilih untuk mendapatkan data dan akan dianalisis menggunakan program SPSS untuk menentukan kebolehpercayaan instrumen kajian berdasarkan pekali Cronbach's Alpha yang mempunyai nilai di antara 0.65 hingga 0.95 (Chua, 2014). 


\section{Analisis Data}

Dalam kajian ini, dua jenis statistik yang di gunakan untuk menganalisis data yang diperoleh iaitu, statistik deskriptif dan statistik inferensi. Pemboleh ubah bebas bagi kajian ini adalah jenis calon SPM dan persekitaran pembelajaran matematik atas talian. Manakala kepuasan pelajar dalam pembelajaran matematik atas talian pula adalah pemboleh ubah bersandar dalam kajian ini. Data primer yang diperoleh daripada responden melalui google form dianalisis dengan menggunakan perisian SPSS bagi mencapai objektif-objektif kajian.

Objektif pertama bagi kajian ini dianalisis dengan menggunakan statistik deskriptif dalam bentuk min, sisihan piawai, kekerapan dan peratusan ke atas kecenderungan responden item dan skala yang telah di tetapkan dalam instrumen yang di sediakan. Analisis ini digunakan untuk menerangkan tahap kepuasan pelajar iaitu calon SPM 2020 terhadap pembelajaran matematik dalam talian. Manakala, objektif kedua dan ketiga dalam kajian ini pula dianalisis dengan menggunakan statistik inferensi di mana data dan maklumat daripada sampel sebagai anggaran kepada data dan maklumat populasi.

Bagi menjawab persoalan pertama, tahap kepuasan pembelajaran matematik dalam talian diukur dengan menggunakan jumlah skor bagi setiap item. Jumlah skor yang diperoleh dibahagikan kepada tiga tahap iaitu rendah, sederhana dan tinggi. Jumlah skor yang rendah menunjukkan bahawa calon SPM 2020 mempunyai tahap kepuasan yang rendah terhadap pembelajaran matematik dalam talian. Manakala, jumlah skor yang tinggi pula memberi makna bahawa calon SPM 2020 mempunyai tahap kepuasan pembelajaran matematik yang rendah. Indikator tahap kepuasan berdasarkan jumlah skor adalah seperti Jadual 1 berikut.

Jadual 1: Tahap kepuasan dan jumlah skor item yang digunakan

\begin{tabular}{ccc|}
\hline \multirow{2}{*}{ Tahap kepuasan } & \multicolumn{2}{c|}{ Julat Skor item } \\
\cline { 2 - 3 } & Pengalaman pembelajaran & Persekitaran pembelajaran \\
\hline Rendah & $19-44$ & $33-77$ \\
Sederhana & $45-70$ & $78-122$ \\
Tinggi & $71-95$ & $123-165$ \\
\hline
\end{tabular}

Bagi menjawab persoalan kedua pula, ujian parametrik iaitu ujian-t antara dua kumpulan (IndependentSample T-Test) digunakan untuk mengukur perbezaan antara calon persendirian dan calon dari sekolah kerajaan dari segi tahap kepuasan pembelajaran matematik atas talian. Sebelum data dianalisis dengan menggunakan ujian-t, beberapa kriteria penggunaan ujian-t sampel bebas di semak terlebih dahulu. Antara kriteria yang patut dipatuhi dalam penggunaan ujian-t sampel bebas adalah i) jenis skala pengukuran data adalah selang atau nisbah; ii) persampelan rawak iaitu setiap responden hanya sekali sahaja dibenarkan terlibat dalam kajian; iii) kenormalan iaitu data sampel yang dikumpulkan mestilah bertaburan normal dan; iv) kehomogenan iaitu setiap set data mempunyai nilai varians yang hampir sama (Veloo \& Raman, 2013; Chua, 2014).

Di samping itu, persoalan ketiga bagi kajian ini, dianalisis dengan menggunakan korelasi Pearson $r$ untuk mengenal pasti hubungan antara tahap kepuasan pembelajaran dan persekitaran pembelajaran matematik atas talian bagi calon SPM 2020. Sebelum data dianalisis, andaian-andaian yang telah ditetapkan dalam penggunaan ujian korelasi juga disemak terlebih dahulu. Antara andaian yang patut dipatuhi adalah i) jenis skala pengukuran data adalah selang atau nisbah; ii) persampelan rawak iaitu setiap responden hanya sekali sahaja dibenarkan terlibat dalam kajian; iii) kenormalan iaitu data sampel yang dikumpul mestilah bertaburan normal dan; iv) hubungan antara dua pemboleh ubah yang di kaji mestilah linear (Veloo \& Raman, 2013).

\section{Hasil Kajian}

\section{Kebolehpercayaan}


Soal selidik yang digunakan untuk mengukur kepuasan pelajar terhadap pembelajaran matematik secara atas talian mengandungi dua konstruk iaitu pengalaman dan persekitaran pembelajaran matematik atas talian. Manakala bilangan item bagi soal selidik ini adalah sebanyak 54 item iaitu 20 item bagi konstruk pengalaman dan 34 item bagi konstruk persekitaran. Jadual 2 menunjukkan bahawa terdapat sepuluh item yang menunjukkan nilai korelasi item-total yang agak tinggi bagi konstruk 1 (item B1, B4, B6, B8, B10, B14, B17, B18, B19 dan B20) manakala 10 lagi item menunjukkan nilai korelasi yang agak lemah kecuali item B5 yang mempunyai nilai negatif iaitu item yang tiada hubungan dengan item-item lain. Di samping itu, konstruk 2 pula mempunyai 22 item yang menunjukkan nilai korelasi item-total yang agak tinggi $(\mathrm{C} 1, \mathrm{C} 2, \mathrm{C} 3, \mathrm{C} 5, \mathrm{C} 6, \mathrm{C} 8, \mathrm{C} 9, \mathrm{C} 10, \mathrm{C} 11, \mathrm{C} 12$, $\mathrm{C} 13, \mathrm{C} 14, \mathrm{C} 15, \mathrm{C} 16, \mathrm{C} 17, \mathrm{C} 18, \mathrm{C} 20, \mathrm{C} 26, \mathrm{C} 27, \mathrm{C} 28, \mathrm{C} 29$ dan C30). Namun begitu, terdapat 12 item yang mempunyai nilai korelasi item-total yang agak rendah kecuali item $\mathrm{C} 4$ yang mempunyai nilai korelasi negatif yang menunjukkan bahawa item $\mathrm{C} 4$ tidak mempunyai hubungan dengan item-item lain. Sehubungan dengan itu, nilai Cronbach Alpha (Jadual 2) bagi konstruk pengalaman dan persekitaran pembelajaran matematik dalam talian adalah 0.812 dan 0.924. Pada keseluruhan, instrumen kepuasan pembelajaran atas talian mempunyai nilai alpha yang tinggi iaitu 0.925 . Hal yang sedemikian menunjukkan bahawa instrumen ini mempunyai nilai kebolehpercayaan yang baik. Boleh dikatakan bahawa kedua-dua konstruk yang mengukur kepuasan pembelajaran matematik atas talian mempunyai nilai alpha yang melebihi 0.70. Namun begitu, selepas ujian kebolehpercayaan dilaksanakan, terdapat item yang digugurkan agar mendapat pekali Cronbach Alpha yang tinggi.

Jadual 2: Nilai kebolehpercayaan Cronbach Alpha instrumen

\begin{tabular}{|c|c|c|c|c|c|c|c|}
\hline Konstruk & \multirow{2}{*}{$\begin{array}{c}\text { Item } \\
20\end{array}$} & \multicolumn{5}{|c|}{ Corrected Item-Total Correlation } & \multirow{2}{*}{$\begin{array}{c}\text { Cronbach } \\
\text { Alpha } \\
.812\end{array}$} \\
\hline 1. Pengalaman & & 494 & .392 & .303 & .535 & -.003 & \\
\hline pembelajaran matematik & & .528 & .225 & .487 & .339 & .584 & \\
\hline atas talian & & 196 & .291 & .255 & .666 & .317 & \\
\hline & & .089 & .558 & .522 & .519 & .424 & \\
\hline \multirow[t]{7}{*}{ 2. Persekitaran } & 34 & .706 & .774 & .452 & -.133 & .724 & .924 \\
\hline & & 663 & 109 & .670 & .541 & .512 & \\
\hline & & .528 & .579 & .503 & .422 & .660 & \\
\hline & & .529 & .569 & .562 & .292 & .403 & \\
\hline & & .379 & .395 & .320 & .081 & .353 & \\
\hline & & .573 & .409 & .673 & .455 & .741 & \\
\hline & & .273 & .446 & .705 & .645 & & \\
\hline $\begin{array}{l}\text { Kepuasan pembelajaran } \\
\text { matematik atas talian }\end{array}$ & 54 & & & & & & .925 \\
\hline
\end{tabular}

Jadual 3 menunjukkan hasil analisis kebolehpercayaan bagi konstruk pengalaman pembelajaran matematik secara atas talian dianalisis di mana pekali Cronbach Alpha adalah 0.812. Namun begitu, dilihat pada bahagian nilai Cronbach Alpha jika item digugurkan dalam Jadual 3, didapati bahawa nilai Cronbach Alpha lebih tinggi daripada nilai asal. Oleh itu, item B5 perlu disingkirkan supaya nilai Cronbach Alpha bagi konstruk ini meningkat menjadi 0.828. Manakala, pada bahagian nilai korelasi item yang diperbetulkan kepada jumlah skor dalam Jadual 2 memberi gambaran bahawa item B5 mempunyai korelasi negatif dengan keseluruhan item di mana nilai korelasi yang rendah menunjukkan bahawa item B5 tidak seragam dengan item-item lain dalam konstruk soal selidik. Keseluruhannya, kebolehpercayaan bagi konstruk ini boleh diterima dan digunakan kepada responden kajian sebenar (Cronbach Alpha $=0.828)$ mengandungi 19 item. Jadual 3 juga menunjukkan hasil analisis kebolehpercayaan bagi konstruk persekitaran pembelajaran matematik atas talian iaitu nilai Cronbach Alpha adalah 0.924. Sebagai peraturan dalam kebolehpercayaan soal selidik, sesuatu soal selidik lebih dipercayai apabila nilai kebolehpercayaannya lebih tinggi iaitu nilai Cronbach Alpha melebihi 0.60 (Cronbach, 1946; Nunnally \& Bernstein, 1994; Bolarinwa, 2015). Jadual 3 menunjukkan bahawa nilai Cronbach Alpha akan meningkat kepada 0.927 apabila item C4 digugurkan dan pada bahagian nilai korelasi item yang diperbetulkan kepada jumlah skor (Jadual 2) pula memberi gambaran bahawa item C4 mempunyai korelasi negatif dengan keseluruhan item. Ini membuktikan bahawa $\mathrm{C} 4$ perlu disingkirkan kerana mempunyai nilai korelasi yang rendah dengan jumlah skor dan tidak mempunyai 
DOI: https://doi.org/10.47405/mjssh.v6i4.752

keseragaman dengan item-item lain yang terdapat dalam konstruk ini (Mohammad Rahim Kamaluddin \& Wan Shahrazad Wan Sulaiman 2019). Hasil analisis, merumuskan bahawa item-item bagi konstruk ini mempunyai ketekalan dalaman yang baik di mana nilai Cronbach Alpha yang melebihi 0.9 dan konstruk ini boleh di guna pakai dalam kajian sebenar apabila item C4 digugurkan. Hal ini menunjukkan bahawa soal selidik ini merupakan satu instrumen yang boleh digunakan dalam kajian sebenar kerana mempunyai tahap kebolehpercayaan yang tinggi (Cronbach, 1946; Nunnally \& Bernstein, 1994; DeVellis, 2003; Sidek, 2005; Cresswell, 2010; Chan, 2014).

Jadual 3: Nilai kebolehpercayaan Cronbach Alpha bagi soal selidik tahap kepuasan pembelajaran matematik atas talian

\begin{tabular}{llccccc}
\hline \multicolumn{1}{c}{ Konstruk } & \multicolumn{5}{c}{ Nilai Cronbach Alpha jika item } & $\begin{array}{c}\text { Cronbach } \\
\text { digugurkan }\end{array}$ \\
\hline 1. Pengalaman pembelajaran & .798 & .804 & .808 & .795 & .828 & .812 \\
matematik atas talian & .798 & .811 & .798 & .806 & .791 & \\
& .816 & .810 & .812 & .790 & .808 & \\
2. Persekitaran pembelajaran & .814 & .796 & .800 & .795 & .802 & .924 \\
matematik atas talian & .920 & .918 & .923 & .927 & .919 & \\
& .922 & .921 & .921 & .922 & .922 & .923 \\
& .922 & .921 & .922 & .925 & .920 & \\
& .924 & .924 & .924 & .926 & .924 & \\
& .921 & .923 & .920 & .923 & .919 & \\
& .924 & .923 & .919 & .921 & & \\
& & & & & & \\
& & & &
\end{tabular}

\section{Ujian Kenormalan}

Hasil analisis yang menggunakan perisian SPSS, didapati bahawa data kajian mempunyai dua nilai ekstrem (outlier) seperti yang ditunjukan dalam Rajah 2 di mana skor responden ke-18 dan ke-59 terletak jauh daripada kotak (Boxplot).

Rajah 2: Boxplot data kepuasan pembelajaran atas talian

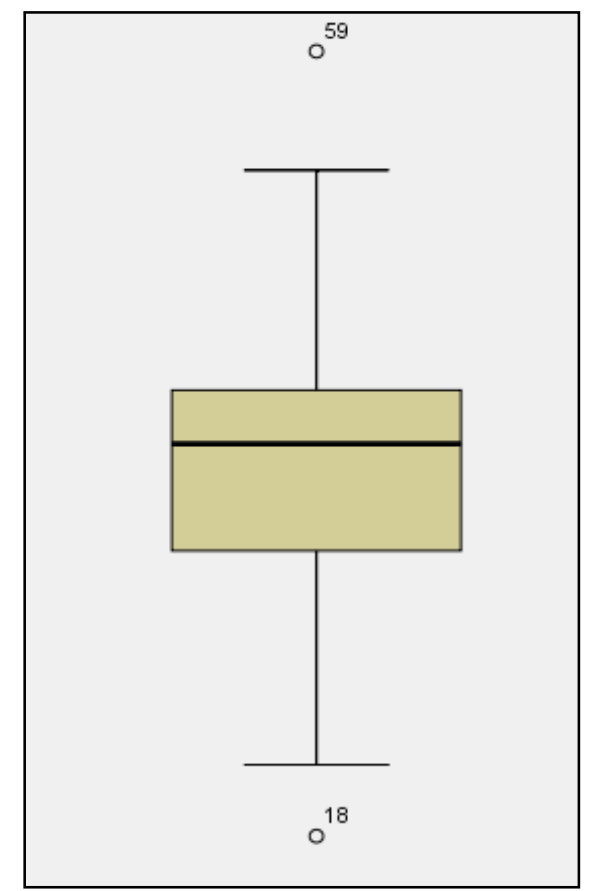

Kedua-dua responden ini telah digugurkan daripada sampel kajian satu per satu sehingga tiada lagi nilai ekstrem yang disumbangkan. Oleh yang demikian, ujian normaliti di laksanakan semula kepada 
58 sampel dan didapati bahawa taburan data bagi 58 sampel kajian, data dianggap normal kerana kedua-dua nilai skweness dan kurtosis berada dalam lingkungan \pm 1.96 iaitu 0.079 dan 0.430 masingmasing. Sehubungan dengan itu, data kajian ini bertaburan normal berdasarkan ujian KolmogorovSmirnov yang menunjukkan bahawa ujian ini tidak signifikan apabila aras signifikan ujian ini adalah $0.200(p>0.05)$.

\section{Tahap Kepuasan Pembelajaran Matematik Atas Talian}

Jadual 4 menunjukkan bahawa tahap kepuasan pembelajaran matematik dari segi persekitaran pembelajaran matematik lebih tinggi $(\min =124.86, \mathrm{sp}=14.20)$ berbanding dengan pengalaman pembelajaran matematik secara atas talian $(\min =67.03, \mathrm{sp}=7.57)$. Secara keseluruhannya, calon SPM 2020 di pusat peperiksaan SMK Seri Kundang mempunyai tahap kepuasan yang tinggi $(\mathrm{min}=191.90$, $\mathrm{sp}=20.49$ ) terhadap pembelajaran matematik secara atas talian sepanjang penutupan sekolah disebabkan oleh pelaksanaan Perintah Kawalan Pergerakan (PKP) seluruh Malaysia.

Jadual 4: Min, sisihan piawai dan tahap kepuasan pembelajaran matematik atas talian

\begin{tabular}{lccc}
\hline \multicolumn{1}{c}{ Konstruk } & Min & Sisihan piawai & Tahap kepuasan \\
\hline Pengalaman pembelajaran matematik & 67.0345 & 7.56716 & Sederhana \\
Persekitaran pembelajaran matematik & 124.8621 & 14.19840 & Tinggi \\
Keseluruhan soal selidik & 191.8966 & 20.48679 & Tinggi \\
\hline
\end{tabular}

\section{Perbezaan Tahap Kepuasan Pembelajaran Matematik Berdasarkan Jenis Calon SPM}

Berdasarkan Jadual 5, ujian-t sampel bebas digunakan untuk membandingkan min skor kepuasan calon SPM 2020 di mana calon kerajaan $(n=30)$ lebih ramai berbanding dengan calon persendirian $(n=28)$. Hasil analisis statistik Kolmogorov-Smirnov menunjukkan andaian kenormalan dipatuhi. Manakala hasil analisis ujian Levene pula tidak signifikan (p>.05), maka keputusan ini telah memenuhi andaian kehomogenan varians antara calon kerajaan dan calon persendirian dalam kepuasan pembelajaran matematik atas talian. Ujian-t sampel bebas dijalankan untuk menentukan kadar kepuasan pembelajaran matematik atas talian. Ujian-t Sampel Bebas adalah tidak signifikan secara statistik iaitu $\mathrm{t}(56)=-0.553, \mathrm{p}>.05$ (dua-ekor). [95\% CI $=-5.11488$ hingga 2.90060]. Hasil analisis ini mendapati bahawa kajian ini gagal menolak $\mathrm{H}_{\mathrm{o}} 1$, di mana tidak terdapat perbezaan yang besar antara min tahap kepuasan pembelajaran matematik secara atas talian bagi calon kerajaan dengan calon persendirian.

Jadual 5: Keputusan bagi kepuasan pembelajaran matematik atas talian berdasarkan jenis calon

\begin{tabular}{lccccccc}
\hline Jenis calon SPM & $\mathrm{N}$ & $\mathrm{min}$ & $\mathrm{sp}$ & $\mathrm{dk}$ & $\mathrm{t}$ & $\mathrm{p}$ & $95 \%$ Confidence Interval \\
\hline Sekolah kerajaan & 30 & 66.5 & 8.05 & 56 & -0.553 & $0.582 *$ & -5.11488 hingga 2.90060 \\
Persendirian & 28 & 67.61 & 7.11 & & & & \\
\hline
\end{tabular}

$* p>.05$

\section{Hubungan Antara Pengalaman Pembelajaran dan Persekitaran Pembelajaran Matematik Atas Talian}

Berdasarkan Jadual 6, analisis ujian korelasi Pearson antara tahap pengalaman pembelajaran matematik dalam talian $(M=67.03, S D=7.57)$ dan persekitaran pembelajaran matematik atas talian $(M=123.86, S D=14.20)$ menunjukkan bahawa wujudnya hubungan linear positif yang kuat dan signifikan antara pengalaman pembelajaran matematik atas talian dengan persekitaran pembelajaran matematik atas talian $[\mathrm{r}(56)=0.749, \mathrm{p}<0.05]$. Kadar varian telah dikira $\left(r^{2}=0.56\right)$ yang menunjukkan bahawa pengalaman pembelajaran matematik secara atas talian menyumbang sebanyak $56 \%$ varian berhubungan dengan varians persekitaran pembelajaran matematik secara atas talian. Kesimpulannya, pengalaman pembelajaran matematik yang tinggi mempunyai persekitaran pembelajaran yang baik, manakala tahap kepuasan pembelajaran matematik yang rendah mempunyai persekitaran pembelajaran yang lemah. 
Malaysian Journal of Social Sciences and Humanities (MJSSH), Volume 6, Issue 4, (page 1 - 20), 2021

DOI: https://doi.org/10.47405/mjssh.v6i4.752

Jadual 6: Keputusan bagi hubungan antara kepuasan dan persekitaran pembelajaran matematik

\begin{tabular}{lccc}
\hline & Pengalaman $(\boldsymbol{r})$ & Persekitaran $(\boldsymbol{r})$ & $\mathbf{N}$ \\
\hline Pengalaman $(r)$ & 1 & 0.749 & 58 \\
Persekitaran $(r)$ & & 1 & 58 \\
\hline
\end{tabular}

$* \mathrm{p}<.05$ (dua ekor)

\section{Perbincangan Kajian}

\section{Tahap Kepuasan Pembelajaran Matematik Atas Talian}

Kajian ini jelas sekali menunjukkan bahawa tahap kepuasan terhadap pembelajaran matematik secara atas talian dalam kalangan calon SPM 2020 di pusat peperiksaan SMK Seri Kundang berada pada tahap yang tinggi. Namun begitu, masih terdapat sebilangan calon yang mempunyai tahap kepuasan yang sederhana terhadap pembelajaran matematik atas talian. Hal yang sedemikian, perlu dibendung agar persepsi yang negatif terhadap pembelajaran matematik secara atas talian tidak dibawa ke peringkat pengajian tinggi dan secara tidak langsung akan mempengaruhi pembelajaran matematik yang di laksanakan secara atas talian apabila berada di peringkat pengajian yang lebih tinggi.

Secara rasminya, dapat disimpulkan bahawa kaedah pembelajaran matematik secara atas talian dilihat memberi kesan yang positif walaupun kaedah pembelajaran ini baru dilaksanakan sepenuhnya pada tahun 2020 di sebabkan oleh penutupan semua sekolah di seluruh Malaysia. Dapatan ini selari dengan beberapa pengkaji terdahulu bahawa kaedah pembelajaran matematik dalam talian dapat memberi kesan yang positif terhadap pencapaian pelajar (Alsalhi et al., 2019; Nieuwoudt, 2020; Nurul et al., 2020; Moreno-Guerreri et al., 2020). Sehubungan dengan itu, pendekatan pembelajaran dalam talian dapat membantu guru dan pelajar untuk menyelesaikan sukatan pembelajaran matematik yang tertinggal apabila semua sekolah di Malaysia diperintahkan tutup bagi mengelakkan penularan jangkitan COVID-19.

Walau bagaimanapun, terdapat sebilangan calon SPM 2020 yang terlibat dalam kajian ini dilaporkan mempunyai tahap kepuasan yang sederhana terhadap pembelajaran matematik dalam talian. Selaras dengan dapatan Krishnan (2016), menunjukkan bahawa pelajar lebih suka terhadap mod pembelajaran semuka berbanding pembelajaran matematik dalam talian kerana mudah untuk berkomunikasi, perbincangan, pemahaman konsep matematik dan dapat meningkatkan pemahaman pembelajaran matematik. Hal ini berkemungkinan kerana mereka kurang berminat dan memberi perhatian semasa kelas matematik dalam talian dilaksanakan. Pendapat ini selari dengan dapatan Mishra (2020) bahawa pelajar memberi reaksi negatif terhadap pembelajaran dalam talian kerana mereka tidak dapat mengekalkan tingkah laku yang baik sepanjang pembelajaran dalam talian dilaksanakan dan juga mereka tidak mampu untuk mengekalkan kemampuan pembelajaran mereka di sebabkan oleh kepantasan guru terhadap pengajaran dalam talian. Bagi meningkatkan lagi peratusan tahap kepuasan pelajar terhadap pembelajaran matematik dalam talian, sokongan daripada guru dan ibu bapa sangat diperlukan (Aliyyah et al., 2020).

Bagi pelajar yang bakal menduduki peperiksaan besar, mereka sangat memerlukan sokongan daripada tenaga pengajar dan ibu bapa supaya semangat belajar mereka tidak merudum disebabkan oleh perubahan pendekatan pembelajaran secara mengejut. Sokongan daripada ibu bapa terhadap pembelajaran dalam talian memberikan sumbangan yang sangat besar. Ibu bapa perlu mempunyai kesedaran tentang fasa perubahan kaedah pembelajaran kini di mana ibu bapa perlu memberi perhatian yang lebih dan mengawasi anak-anak berhadapan dengan kelas atas talian. Oleh itu, ibu bapa perlu memainkan peranan sebagai seorang guru di rumah dengan memantau perkembangan anak-anak supaya mengikuti kelas atas talian mengikut jadual yang ditetapkan dan mengawasi kandungan yang di layari oleh pelajar. Sokongan ibu bapa perlu diteruskan sepanjang proses pembelajaran secara atas talian berlangsung supaya semangat anak-anak tidak merudum terhadap pembelajaran matematik secara atas talian. 
Manakala bagi pelajar yang kurang berkemampuan untuk mengakses kelas dalam talian pula, tidak boleh dipinggirkan disebabkan mereka tidak mempunyai kemudahan ICT atau tinggal kawasan yang tidak mempunyai capaian akses internet yang berkualiti. Di sini, guru perlu memainkan peranan penting untuk memastikan pelajar tidak ketinggalan dalam proses pembelajaran. Guru perlu mengambil inisiatif untuk memastikan proses pembelajaran berlangsung dengan menyediakan nota-nota dan tugasan yang dihantar ke rumah pelajar melalui pos atau menghantar sendiri ke tangan pelajar. Secara tidak langsung, perkara ini dapat memberi motivasi kepada pelajar untuk terus belajar walaupun tiada pembelajaran bersemuka dan tidak dapat mengakses pembelajaran secara atas talian. Pendapat ini selaras dengan dapatan Cho dan Heron (2015), di mana hanya pemboleh ubah motivasi yang mempengaruhi kepuasan pelajar, manakala, strategi pembelajaran tidak memberi pengaruh kepada kepuasan pelajar terhadap pembelajaran matematik. Manakala, kajian Davis (2017) didapati bahawa prestasi dan kepuasan pelajar terhadap pembelajaran matematik dalam talian tidak bergantung dengan strategi pembelajaran pelajar.

\section{Perbezaan Tahap Kepuasan Pembelajaran Matematik Berdasarkan Jenis Calon SPM}

Secara keseluruhannya, tahap kepuasan pembelajaran matematik secara atas talian berada pada tahap yang tinggi. Selain itu, tidak terdapat perbezaan min yang ketara dari segi tahap kepuasan pembelajaran matematik secara atas talian antara dua jenis calon SPM 2020 iaitu calon persendirian dengan calon dari sekolah kerajaan. Ini bermakna tahap kepuasan calon persendirian terhadap pembelajaran matematik secara atas talian adalah konsisten dengan tahap kepuasan calon dari sekolah kerajaan terhadap pembelajaran matematik dalam talian. Di sebabkan oleh tiada lagi kajian dalam konteks ini, dapatan ini mewakili sumbangan baru dalam bidang pendidikan matematik dalam talian.

Dalam kajian ini, tahap kepuasan calon SPM terhadap pembelajaran matematik adalah berdasarkan pengalaman pembelajaran dalam talian di mana pengkaji tidak mengambil kira jenis platform yang digunakan oleh pelajar. Pembelajaran matematik dalam talian yang berkesan mestilah menggunakan platform yang bersesuaian dengan bahasa dan simbol matematik. Secara umumnya mengetahui bahawa salah satu ciri istimewa matematik adalah bahasa dan simbol yang digunakan berbeza dengan bahasa bukan mata pelajaran matematik. Platform yang digunakan untuk pembelajaran matematik dalam talian mestilah mempunyai ciri-ciri di mana guru dapat menyediakan aktiviti dan penyelesaian masalah matematik supaya pelajar dapat mengikuti langkah demi langkah dalam penyelesaian masalah matematik walaupun pembelajaran tidak bersemuka (Ahn \& Edwin, 2018).

Terdapat pengkaji terdahulu yang menegaskan bahawa ciri-ciri pelajar seperti jantina dan umur tidak mempengaruhi tahap kepuasan pelajar terhadap persekitaran pembelajaran dalam talian tetapi tindakan pelajar itu sendiri yang mempengaruhi pembelajaran dalam talian (Thurmond et al., 2002). Namun setelah 15 tahun, penyataan itu disangkal oleh Davis (2017) yang menyatakan bahawa ciri-ciri pelajar menjadi salah satu pengaruh kepada kepuasan pembelajaran dalam talian. Davis (2017) telah membuktikan melalui kajian beliau dan mendapati bahawa tiada perbezaan antara lelaki dan perempuan terhadap kepuasan dan prestasi pembelajaran matematik dalam talian. Beliau juga mendapati bahawa perspektif umur sangat penting untuk mengukur kepuasan pembelajaran matematik secara talian tetapi tidak penting untuk mengukur prestasi mata pelajaran matematik dalam talian (Davis 2017). Daripada perspektif umur, Davis (2017) memilih golongan pelajar bergenerasi X dan generasi Y di mana generasi X lebih berusia daripada generasi Y. Dalam kajian Davis (2017), di dapati bahawa pelajar yang berusia kurang berpuas hati dengan pembelajaran matematik secara dalam talian berbanding pelajar muda.

\section{Hubungan Antara Pengalaman dan Persekitaran Pembelajaran Matematik Atas Talian}

Secara keseluruhannya, terdapat hubungan antara pengalaman pembelajaran matematik atas talian dengan persekitaran pembelajaran matematik secara atas talian. Berdasarkan analisis yang telah di laksanakan, jelas bahawa terdapat hubungan yang positif antara pengalaman pembelajaran matematik atas talian dengan persekitaran pembelajaran matematik secara atas talian. Hal yang sedemikian menunjukkan bahawa calon yang mempunyai pengalaman pembelajaran yang tinggi terhadap 
pembelajaran matematik secara atas talian lebih mempunyai persekitaran pembelajaran yang baik terhadap pembelajaran matematik secara atas talian.

Hasil daripada analisis, dapat disimpulkan bahawa calon SPM 2020 yang berpuas hati dengan kualiti pembelajaran matematik iaitu berdasarkan pengalaman pembelajaran segerak dalam persekitaran pembelajaran secara atas talian. Selaras dengan pendapat Cole (2014), pembelajaran segerak memberi peluang kepada pelajar untuk menjawab soalan apabila mendapat arahan soalan secara langsung dan guru pula dapat menjelaskan secara langsung kepada pelajar apabila pelajar mengalami kesukaran menjawab soalan yang diberikan. Hal yang sedemikian kerana interaksi yang berlaku antara pelajar dengan guru atau dengan pelajar lain dapat menyumbang perasaan tentang kewujudan komuniti pembelajaran seperti komuniti pembelajaran semuka di dalam kelas di mana komuniti ini dapat memberi sokongan tambahan kepada pelajar untuk mengembangkan kefahaman terhadap sesuatu topik matematik yang dibincangkan. Di samping itu, Karal et al. (2015) mendapati bahawa persekitaran pembelajaran matematik dalam talian menjadi lebih bermanfaat kepada pelajar dan mempunyai tahap interaksi yang tinggi apabila pen digital digunakan oleh guru dan pelajar semasa kelas segerak berlangsung.

Melalui persekitaran pembelajaran dalam talian, guru dapat menyediakan dan menyampaikan pelbagai bahan pembelajaran matematik melalui sumber digital seperti video pendidikan, pengajaran melalui platform, persidangan video, rangkaian media sosial Shakah et al., 2019). Manakala pelajar pula dapat mencapai kandungan matematik melalui teknologi seperti komputer desktop, komputer riba, tablet, telefon pintar dan televisyen (Laskaris et al., 2019). Perkara ini dapat membantu pelajar menyelesaikan tugasan matematik seperti menonton video pendidikan matematik berkaitan penyelesaian masalah matematik. Hal ini selaras dengan dapatan Alqurahi (2020), di mana pelajar yang mempunyai tahap kepuasan pembelajaran yang tinggi adalah pelajar yang mempunyai persekitaran pembelajaran atas talian yang baik di mana kandungan pembelajaran mudah diakses tanpa mengira waktu dan tempat.

Pengalaman pembelajaran dalam talian sama ada pembelajaran segerak (synchronous) atau tidak segerak (asynchronous) juga memberikan impak kepada kepuasan pelajar terhadap pembelajaran matematik. Hal ini selaras dengan dapatan Nieuwoudt (2020), di mana pelajar yang mempunyai pengalaman pembelajaran segerak (synchronous) tidak semestinya memperolehi gred pencapaian matematik yang tinggi. Hal ini kerana, pelajar yang tidak dapat menghadiri kelas segerak (synchronous) masih dapat mencapai kandungan pembelajaran dengan menonton video kelas segerak yang telah dirakam oleh guru mereka dengan berulang kali sehingga mereka faham akan kandungan yang disampaikan. Oleh itu, pelajar dapat meneruskan proses pembelajaran dan dapat menghabiskan sukatan pembelajaran matematik walaupun tidak dapat menghadiri kelas bersemuka atau kelas matematik dalam talian yang segerak. Selaras dengan dapatan Matzakos (2017), bahawa lebih daripada 70 peratus respondennya (78 pelajar) bersetuju dengan pembelajaran matematik dalam talian dan bersetuju bahawa pendekatan ini harus merangkumi keseluruhan sukatan pembelajaran matematik. Ini menunjukkan bahawa pelajar lebih tertarik dengan pembelajaran matematik yang menggunakan pendekatan atas talian dan pelajar dan pelajar selesa dengan persekitaran, alat dan bahan pembelajaran yang di gunakan. Pengalaman pembelajaran matematik dalam talian dapat membantu pelajar dalam peperiksaan akhir, di mana pendekatan ini dapat diperluaskan kepada keseluruhan sukatan pelajaran matematik (). Oleh itu, penglibatan pelajar yang meluas terhadap pembelajaran matematik dalam talian dapat menyumbang kepada penerimaan pelajar terhadap pembelajaran matematik dalam talian.

\section{Implikasi Kepada Amalan Pendidikan}

Di kala dunia dilanda wabak COVID-19, UNESCO menyarankan bahawa semua institusi pendidikan ditutup dan konsep sekolah dari rumah di perkenalkan iaitu pembelajaran dalam talian menggantikan pembelajaran semuka (UNESCO 202). Bagi memastikan pelajar tidak ketinggalan dalam mengikuti pembelajaran, guru-guru telah menggunakan pendekatan pembelajaran atas talian untuk melaksanakan kelas. Walaupun sekolah di tutup, tiada alasan untuk tidak meneruskan pembelajaran kerana pembelajaran dalam talian merupakan penyelesaian bagi isu ini dan pelajar masih dapat belajar walaupun dalam keadaan terhad. Oleh itu, guru dengan pelajar memanfaatkan penggunaan Teknologi 
Maklumat Komunikasi (TMK) melalui pembelajaran dalam talian yang selaras dengan Kementerian Pendidikan Malaysia (KPM) di dalam Pelan Pembangunan Pendidikan Malaysia 2013-2025. Berikut merupakan implikasi bagi pengajaran dan pembelajaran atas talian kepada pendidikan matematik.

Dalam bidang pendidikan matematik, pengajaran dan pembelajaran (PdP) dalam talian akan berkesan apabila guru menggunakan pedagogi pendidikan dalam talian yang sesuai, guru dan pelajar berkomunikasi dengan aktif sepanjang proses PdP, guru mendorong pelajar untuk berinteraksi dengan rakan sekelas, guru menggunakan sumber digital dan teknologi yang dapat menyokong pembelajaran matematik iaitu dapat menyokong ayat dan simbol dalam matematik. Selaras dengan teori pendidikan jarak jauh, transactional distance theory yang mencadangkan bahawa guru perlu mengambil berat terhadap tiga unsur supaya dapat menjayakan sesuatu pembelajaran dalam talian iaitu dialog, struktur dan autonomi pelajar di mana ketiga-tiga unsur ini membantu mengurangkan rasa jarak yang di alami oleh pelajar (Moore, 1993). Hal ini kerana jarak yang dirasakan oleh pelajar dalam pembelajaran atas talian akan menimbulkan rasa terpencil dan berkemungkinan akan berhenti daripada mengambil bahagian semasa proses pembelajarannya. Pendekatan pembelajaran matematik dalam talian adalah lebih mudah kerana guru tidak perlu memberi perhatian terhadap perbezaan cara pembelajaran dan ciriciri pembelajaran dalam talian. Sebaliknya, guru perlu fokus terhadap perlaksanaan dan perkembangan bahan pengajaran matematik yang digunakan dan aktiviti pembelajaran matematik yang berkesan melalui pembelajaran dalam talian (Davis, 20017).

\section{Cadangan Kajian Lanjutan}

Berdasarkan kepada dapatan kajian dan implikasi yang dibincangkan terhadap pembelajaran atas talian, maka pada bahagian ini, pengkaji memberi fokus kepada cadangan-cadangan untuk menambahbaikkan kajian berkaitan pembelajaran matematik dalam talian. Dalam kajian lanjutan, pemboleh ubah demografi pelajar perlu dipertimbangkan semasa membuat perbandingan bagi hasil dapatan kajian yang mungkin dapat dikaitkan dengan prestasi dan kepuasan terhadap pembelajaran matematik dalam talian. Antara demografi yang perlu dipertimbangkan adalah ciri-ciri pelajar, strategi pembelajaran matematik dan persekitaran pembelajaran matematik dalam talian. Selain itu, pengkaji juga mencadangkan kajian lanjutan untuk melihat hubungan antara beberapa pemboleh ubah iaitu ciri-ciri pelajar, strategi pembelajaran matematik dan persekitaran pembelajaran matematik dalam talian.

Hasil analisis kajian ini mendapati bahawa tidak terdapat perbezaan tahap kepuasan pembelajaran matematik dalam talian calon SPM persendirian dengan calon SPM dari sekolah kerajaan. Namun begitu, terdapat perbezaan min yang kecil antara kedua-dua jenis calon SPM ini. Dapatan ini berkemungkinan di sebabkan oleh saiz sampel yang digunakan agak kecil, pengkaji mencadangkan supaya kajian lanjutan dibuat pada skala yang besar iaitu memilih sampel daripada beberapa daerah atau negeri di Malaysia. Saiz sampel yang besar berkemungkinan mempunyai dapatan yang berbeza dengan kajian semasa dan secara langsung dapat menggeneralisasikan kepada seluruh calon SPM di Malaysia. Oleh itu, kajian ini boleh di jadikan sebagai kajian rintis bagi kajian lanjutan.

Instrumen yang digunakan dalam kajian ini adalah soal selidik Community of inquiry (CoI) dan Student Satisfaction Scale (SSS) di mana kedua - dua soal selidik ini telah di sahkan oleh pengkaji terdahulu dan merupakan instrumen yang boleh dipercayai. Namun soal selidik ini dibina untuk kegunaan peringkat pengajian tinggi dan secara umumnya kedua-dua soal selidik ini digunakan untuk mengukur kepuasan bagi sebarang mata pelajaran dalam talian. Oleh itu, kedua-dua instrumen ini perlu menjalani proses kesahan dan kebolehpercayaan yang mendalam supaya dapat digunakan kepada pelajar sekolah menengah. Sebagai contoh, CoI dan SSS boleh disahkan untuk mata pelajaran matematik peringkat sekolah menengah yang diajar dalam persekitaran atas talian.

\section{Kesimpulan}

Kesimpulannya, kajian ini dilaksanakan untuk mengenal pasti sama ada calon SPM 2020 berpuas hati atau tidak terhadap pembelajaran matematik dalam talian sepanjang perintah kawalan pergerakan 
dilaksanakan di seluruh Malaysia. Kepuasan pelajar yang dilihat dalam kajian ini adalah berdasarkan pengalaman mereka terhadap pembelajaran matematik dalam talian sepanjang penutupan sekolah. Erti kata lain bermaksud pelajar berpuas hati dengan apa yang mereka belajar dan bagaimana keadaan mereka belajar pelajaran matematik dalam kelas atas talian yang di laksanakan. Sehubungan dengan itu, kajian ini menunjukkan hasil bahawa tahap kepuasan pelajar terhadap pembelajaran matematik terletak pada tahap kepuasan yang tinggi walaupun pembelajaran yang dilaksanakan tidak bersemuka. Kebanyakan pelajar yang terlibat dalam kajian ini mempunyai tidak mempunyai pengalaman yang lama terhadap pembelajaran matematik dalam talian di mana pelajar yang terlibat dalam kajian ini pertama kali diperkenalkan dengan pendekatan ini pada bulan Mac 2020. Kajian ini juga membuktikan bahawa terdapat hubungan antara pengalaman dan persekitaran pembelajaran matematik dalam talian.

Kawalan pergerakan yang di sebabkan pandemik COVID-19 telah memberi kesan yang besar terhadap semua sektor seluruh dunia. Oleh sebab pandemik COVID-19, semua institusi pendidikan di seluruh dunia beralih pendekatan pembelajaran iaitu daripada pembelajaran bersemuka kepada pembelajaran dalam talian atau lebih dikenali dengan program pendidikan jarak jauh. Secara umumnya mengetahui bahawa, pandemik COVID-19 memberikan perubahan yang ketara dalam bidang pendidikan sekolah rendah dan menengah dari segi pendekatan pembelajaran iaitu dari pendekatan bersemuka berubah kepada pendekatan dalam talian. Oleh itu, kementerian pelajaran perlu mempertimbangkan beberapa langkah untuk mengembangkan kurikulum bagi memastikan tidak terdapat gangguan pembelajaran di mana kementerian perlu memastikan alat komunikasi yang sedia ada boleh digunakan dengan sebaiknya. Selain itu, kementerian juga perlu mempromosikan teknologi yang sesuai digunakan untuk pembelajaran supaya pelajar dapat merapatkan jurang perbezaan yang wujud dalam sistem pendidikan sebelum dan selepas pandemik COVID-19. Berikutan dengan pandemik ini, setiap pelajar sekolah menengah perlu belajar untuk hidup dan bertahan dengan krisis pandemik ini kerana ini adalah permulaan bagi amalan pendidikan yang inovatif dan secara langsung dapat mempromosikan pendekatan ini yang selaras dengan kemajuan teknologi maklumat dan komunikasi.

\section{Penghargaan}

Terima kasih kepada geran penyelidikan Dana Khas Penyelidikan FPEND COVID-19, GG-2020-025 kerana membantu penghasilan dan penerbitan artikel ini.

\section{Rujukan}

Ahmad Shakir, N. S. B., \& Adnan, N. H. B. (2020). Kebolehgunaan Massive Open Online Course (MOOC) Sebagai E-Pembelajaran dalam Pengajaran Pengaturcaraan di Sekolah Menengah. Malaysian Journal of Social Sciences and Humanities (MJSSH). https://doi.org/10.47405/mjssh.v5i6.429

Ahn, J. Y., \& Edwin, A. (2018). An e-learning model for teaching mathematics on an open source learning platform. International Review of Research in Open and Distance Learning. https://doi.org/10.19173/irrodl.v19i5.3733

Akyol, Z., \& Garrison, D. R. (2008). The Development of A Community of Inquiry Over Time in An Online Course: Understanding The Progression and Integration of Social, Cognitive and Teaching Presence. Online Learning. https://doi.org/10.24059/olj.v12i3.72

Albano, G., \& Dello Iacono, U. (2019). GeoGebra in e-learning environments: a possible integration in mathematics and beyond. Journal of Ambient Intelligence and Humanized Computing. https://doi.org/10.1007/s12652-018-1111-x

Allen, I. E., \& Seaman, J. (2016). Online report card: Tracking online education in the United States. Babson Survey Research Group. Babson College, 231 Forest Street, Babson Park, MA 02457.

Allen, I. Elaine, Seaman, Jeff, Poulin, Russell, Straut, T. T. (2016). Online Report Card. Babson Survey Reserach Group and Quahog Research Group, LLC.

Alsalhi, N. R., Eltahir, M. E., \& Al-Qatawneh, S. S. (2019). The effect of blended learning on the achievement of ninth grade students in science and their attitudes towards its use. Heliyon. https://doi.org/10.1016/j.heliyon.2019.e02424 
Alzahrani, M. G. (2017). The effect of using online discussion forums on students' learning. Turkish Online Journal of Educational Technology.

Arbaugh, J. B., Cleveland-Innes, M., Diaz, S. R., Garrison, D. R., Ice, P., Richardson, J. C., \& Swan, K. P. (2008). Developing a community of inquiry instrument: Testing a measure of the Community of Inquiry framework using a multi-institutional sample. Internet and Higher Education. https://doi.org/10.1016/j.iheduc.2008.06.003

Ashley, T. (2020). Malaysia announces movement control order after spike in Covid-19 cases (updated) | The Star Online. The Star.

Bao, W. (2020). COVID -19 and online teaching in higher education: A case study of Peking University. Human Behavior and Emerging Technologies. https://doi.org/10.1002/hbe2.191

Beomkyu, C. (2016). How people learn in an asynchronous online learning environment: The relationships between graduate students' learning strategies and learning satisfaction. Canadian Journal Of Learning \& Technology.

Berawi, F. M. (2017). Metodologi penyelidikan: Panduan menulis tesis. UUM Press.

Bolarinwa, O. (2015). Principles and methods of validity and reliability testing of questionnaires used in social and health science researches. Nigerian Postgraduate Medical Journal. https://doi.org/10.4103/1117-1936.173959

Boz, B., \& Adnan, M. (2017). How do Freshman Engineering Students Reflect an Online Calculus Course? International Journal of Education in Mathematics, Science and Technology. https://doi.org/10.18404/ijemst.83046

Cho, M. H., \& Heron, M. L. (2015). Self-regulated learning: the role of motivation, emotion, and use of learning strategies in students' learning experiences in a self-paced online mathematics course. Distance Education. https://doi.org/10.1080/01587919.2015.1019963

Chua, Y. P. (2014). Asas Statistik Penyelidikan Edisi Ketiga. In Kaedah dan Statistik Penyelidikan Buku 2.

Chua, Y. P. (2014). Kaedah Penyelidikan Edisi Ketiga. In Kaedah dan Statistik Penyelidikan Buku 1.

Clayton, J. (2007). The validation of the online learning environment survey. ASCILITE 2007 - The Australasian Society for Computers in Learning in Tertiary Education.

Creswell, J. W. (2012). Educational research: Planning, conducting, and evaluating quantitative and qualitative research. In Educational Research.

Davis, A. (2016). Measuring Student Satisfaction in Online Mathematics Courses -- RESEARCH. Kentucky Journal of Excellence in College Teaching and Learning.

Dziuban, C., Moskal, P., Thompson, J., Kramer, L., DeCantis, G., \& Hermsdorfer, A. (2015). Student satisfaction with online learning: Is it a psychological contract? Journal of Asynchronous Learning Network. https://doi.org/10.24059/olj.v19i2.496

El Mamoun, B., Erradi, M., \& El Mhouti, A. (2018). Using an intelligent tutoring system to support learners' WMC in e-learning: Application in mathematics learning. International Journal of Emerging Technologies in Learning. https://doi.org/10.3991/ijet.v13i12.8938

Fauzi, H., Jamal, A., \& Mohd Saifoul, Z. N. (2014). Kaedah Penyelidikan dan Analisis Data SPSS. In Penerbit Universiti Utara Malaysia.

Garrison, D. R. (2011). Communities of Inquiry in Online Learning. In Encyclopedia of Distance Learning, Second Edition. https://doi.org/10.4018/978-1-60566-198-8.ch052

Garrison, D. R. (2019). ONLINE COMMUNITY OF INQUIRY REVIEW: SOCIAL, COGNITIVE, AND TEACHING PRESENCE ISSUES. Online Learning. https://doi.org/10.24059/olj.v11i1.1737

Garrison, D. R. (2019). ONLINE COMMUNITY OF INQUIRY REVIEW: SOCIAL, COGNITIVE, AND TEACHING PRESENCE ISSUES. Online Learning. https://doi.org/10.24059/olj.v11i1.1737

Garrison, D. R., Anderson, T., \& Archer, W. (2010). The first decade of the community of inquiry framework: A retrospective. Internet and Higher Education. https://doi.org/10.1016/j.iheduc.2009.10.003

Goh, C. F., Leong, C. M., Kasmin, K., Hii, P. K., \& Tan, O. K. (2017). Students' experiences, learning outcomes and satisfaction in e-learning. Journal of E-Learning and Knowledge Society. https://doi.org/10.20368/1971-8829/1298 
Gray, J. A., \& DiLoreto, M. (2016). The Effects of Student Engagement, Student Satisfaction, and Perceived Learning in Online Learning Environments This. NCPEA International Journal of Educational Leadership Preparation.

Gu, P., \& Lee, Y. (2019). Promoting Students' Motivation and Use of SRL Strategies in the WebBased Mathematics Learning Environment. Journal of Educational Technology Systems. https://doi.org/10.1177/0047239518808522

Harsasi, M., \& Sutawijaya, A. (2018). Determinants of student satisfaction in online tutorial: A study of a distance education institution. Turkish Online Journal of Distance Education. https://doi.org/10.17718/tojde.382732

Jaggars, S. S. (2014). Choosing Between Online and Face-to-Face Courses: Community College Student Voices. American Journal of Distance Education. https://doi.org/10.1080/08923647.2014.867697

Kamaluddin, M. R., \& Sulaiman, W. S. W. (2017). Teknik kesahan dan kebolehpercayaan alat ujian psikologi. Bangi, Malaysia: Penerbit UKM.

Karal, H., Kokoc, M., Colak, C., \& Yalcin, Y. (2020). A Case Study on Online Mathematics Teaching with Pen-based Technology: Experiences of Two Instructors. Contemporary Educational Technology. https://doi.org/10.30935/cedtech/6157

Kementerian Kesihatan Malaysia 2020. MyHEALTH For Life: Perjuangan Malaysia Memutuskan Rantaian COVID-19. Putrajaya: Kementerian Kesihatan Malaysia.

Lim, J., Kim, M., Chen, S. S., \& Ryder, C. E. (2008). An empirical investigation of student achievement and satisfaction in different learning environments. Journal of Instructional Psychology.

Malaysia Education Blueprint, M. (2013). Malaysia Education Blueprint 2013 - 2025. Education. https://doi.org/10.1016/j.tate.2010.08.007

Matzakos, N. M., \& Kalogiannakis, M. (2018). An analysis of first year engineering students' satisfaction with a support distance learning program in mathematics. Education and Information Technologies. https://doi.org/10.1007/s10639-017-9641-y

Mayer, G., Lingle, J., \& Usselman, M. (2017). Experiences of advanced high school students in synchronous online recitations. Educational Technology and Society.

Mishra, L., Gupta, T., \& Shree, A. (2020). Online teaching-learning in higher education during lockdown period of COVID-19 pandemic. International Journal of Educational Research Open. https://doi.org/10.1016/j.ijedro.2020.100012

Mokhtar, N. (2020). Pembelajaran Atas Talian Untuk Pembelajaran Sepanjang Hayat. UTM NewsHub. https://news.utm.my/ms/2020/04/pembelajaran-atas-talian-untuk-pembelajaran-sepanjanghayat/

Moreno-Guerrero, A. J., Aznar-Díaz, I., Cáceres-Reche, P., \& Alonso-García, S. (2020). E-learning in the teaching of mathematics: An educational experience in adult high school. Mathematics. https://doi.org/10.3390/MATH8050840

Msomi, A. M., \& Bansilal, S. (2018). The experiences of first-year students in mathematics in using an e-learning platform at a university of technology. South African Journal of Higher Education. https://doi.org/10.20853/32-5-2507

Nortvig, A. M., Petersen, A. K., \& Balle, S. H. (2018). A literature review of the factors influencing elearning and blended learning in relation to learning outcome, student satisfaction and engagement. Electronic Journal of E-Learning.

Panyajamorn, T., Suanmali, S., Kohda, Y., Chongphaisal, P., \& Supnithi, T. (2018). Effectiveness of E-Learning Design in Thai Public Schools. Malaysian Journal of Learning and Instruction.

Picciano, A. G. (2017). Theories and frameworks for online education: Seeking an integrated model. In Online Learning Journal. https://doi.org/10.24059/olj.v21i3.1225

Potter, J. (2015). Applying a hybrid model: Can it enhance student learning outcomes? Journal of Instructional Pedagogies.

Reju, C. O. (2016). Students' experiences with distance and online learning of university-level undergraduate mathematics in nigeria comfort okwuegbune reju. International Review of Research in Open and Distributed Learning.

Reju, C. O., \& Jita, L. C. (2018). Instructional delivery and students' experiences with distance and online learning of undergraduate mathematics in Nigeria. International Review of Research in Open and Distance Learning. https://doi.org/10.19173/irrodl.v19i2.3196 
Rios, T., Elliott, M., \& Mandernach, B. J. (2018). Efficient instructional strategies for maximizing online student satisfaction. Journal of Educators Online. https://doi.org/10.9743/jeo.2018.15.3.7

Ryan, S., Kaufman, J., Greenhouse, J., She, R., \& Shi, J. (2016). The effectiveness of blended online learning courses at the community college level. Community College Journal of Research and Practice. https://doi.org/10.1080/10668926.2015.1044584

Saleh, N. S., \& Rosli, M. S. (2020). Systematic Literature Review:Online Social Media Interaction in Education and Employment Cluster/ Tinjauan Literatur Sistematik: Interaksi Media Sosial Atas Talian dalam Kluster Pendidikan dan Pekerjaan. Sains Humanika. https://doi.org/10.11113/sh.v12n3.1744

Smith, G. G., \& Ferguson, D. (2005). Student attrition in mathematics e-learning. Australasian Journal of Educational Technology. https://doi.org/10.14742/ajet.1323

Swan, K. P., Richardson, J. C., Ice, P., Garrison, D. R., Cleveland-innes, M., \& Arbaugh, J. Ben. (2008). Validating a measurement tool of presence in online communities of inquiry. E-Mentor. https://doi.org/7

Tezer, M., \& Çimşir, B. T. (2018). The impact of using mobile-supported learning management systems in teaching web design on the academic success of students and their opinions on the course. Interactive Learning Environments. https://doi.org/10.1080/10494820.2017.1337037

Tezer, M., Yildiz, E. P., Bozkurt, S., \& Tangul, H. (2019). The influence of online mathematics learning on prospective teachers mathematics achievement: The role of independent and collaborative learning. World Journal on Educational Technology: Current Issues. https://doi.org/10.18844/wjet.v11i4.4361

Tolu, A. T. (2013). Creating Effective Communities of Inquiry in Online Courses. Procedia - Social and Behavioral Sciences. https://doi.org/10.1016/j.sbspro.2013.01.157

UNESCO. (2020). 1.37 billion students now home as COVID-19 school closures expand, ministers scale up multimedia approaches to ensure learning continuity. Unesco.

UNESCO. (2020). Distance learning strategies in response to COVID-19 school closures. In UNESCO COVID-19 Education Response Education Sector issue notes.

Veloo, A., \& Raman, A. (2013). Kaedah analisis \& interpretasi data. In Universiti Utara Malaysia Press.

Williamson, T. (2018). ALTERNATIVE LOGICS AND APPLIED MATHEMATICS. NousSupplement: Philosophical Issues. https://doi.org/10.1111/phis.12131

Wu, J. H., Tennyson, R. D., \& Hsia, T. L. (2010). A study of student satisfaction in a blended elearning system environment. Computers and Education. https://doi.org/10.1016/j.compedu.2009.12.012

Yu, T., \& Richardson, J. C. (2015). An exploratory factor analysis and reliability analysis of the student online learning readiness (SOLR) instrument. Online Learning Journal. https://doi.org/10.24059/olj.v19i5.593 